\title{
USE OF FISHPOND SEDIMENT FOR SUSTAINABLE AQUACULTURE-AGRICULTURE FARMING
}

\author{
M.M. RAHMAN \& A. YAKUPITIYAGE \\ Aquaculture and Aquatic Resources Management, School of Environment, Resources and Development, \\ Asian Institute of Technology, Pathumthani, Thailand.
}

\begin{abstract}
An experiment was carried out in triplicate, in $1 \times 1 \mathrm{~m}^{2}$ plots using six treatments, viz. zero input control $\left(\mathrm{S}_{0} \mathrm{~N}_{0} \mathrm{P}_{0} \mathrm{~K}_{0}\right)$, fertilizer control $\left(\mathrm{S}_{0} \mathrm{NPK}\right)$, sediment $60 \mathrm{~kg}$ without fertilizer $\left(\mathrm{S}_{60} \mathrm{~N}_{0} \mathrm{P}_{0} \mathrm{~K}_{0}\right)$, sediment $60 \mathrm{~kg}$ with $\mathrm{N}$ and $\mathrm{K}\left(\mathrm{S}_{60} \mathrm{NP}_{0} \mathrm{~K}\right)$, sediment $120 \mathrm{~kg}$ without fertilizer $\left(\mathrm{S}_{120} \mathrm{~N}_{0} \mathrm{P}_{0} \mathrm{~K}_{0}\right)$ and sediment $120 \mathrm{~kg}$ with $\mathrm{N}$ and $\mathrm{K}$ $\left(\mathrm{S}_{120} \mathrm{NP}_{0} \mathrm{~K}\right)$ to determine the potential of tilapia pond sediment to supply $\mathrm{P}$ to morning glory, and the effects on the soil aggregate stability and the bulk density. The application of 60 and $120 \mathrm{~kg}$ sediment plot $^{-1}$ corresponds $^{-}$ to $30 \%$ and $60 \%$ of the plot soil by weight, respectively. The study confirmed that the application of tilapia pond sediment at $30 \%$ to farm soils with supplementation of $\mathrm{N}$ and $\mathrm{K}$, i.e. the treatment $\mathrm{S}_{60} \mathrm{NP}_{0} \mathrm{~K}$, provided the required amount of $\mathrm{P}$ to morning glory and gave fresh and dry matter yields of morning glory equal to the fertilizer control plot. Furthermore, the application of $30 \%$ sediment significantly improved the soil aggregate stability and decreased the bulk density of farm soils to favorable levels. This kind of integration would ensure long-term sustainability of both aquaculture and agriculture farming.

Keywords: tilapia pond sediment, $P$ supplementation, soil aggregate stability, bulk density
\end{abstract}

\section{INTRODUCTION}

Fertilization and regular feeding using organic manures, inorganic fertilizers and supplementary feeds are common practices for pond fish culture resulting in sedimentation, organic matter (OM) and nutrient accumulation in the pond bottom. This consequently trims down the pond depth and space available for the fish, and makes the water environment unfavorable for fish production through depletion of dissolved oxygen and release of toxic $\mathrm{H}_{2} \mathrm{~S}$ and $\mathrm{NO}_{2}[1,2]$. Sediment removal from pond is therefore an essential practice [3], and its agricultural use could be considered as the best management option, which reduces the negative impacts of aquaculture on the environment. The pond sediment is enriched with OM and plant nutrients, especially very high levels of plant available P [4], which qualifies the sediment as a resource rather than a waste. Intensive land use systems have resulted in the decline of soil fertility and the destruction of soil structure [5]. In most of the tropical soil, P is one of the limiting plant nutrients [6]. Nutrient depletion in soil adversely affects the soil quality and reduces the crop yield, and consequently poses a potential threat to global food security and agricultural sustainability [7]. The application of pond sediment to agricultural land could supply $\mathrm{P}$ for plants and improve the soil structure, thus bringing sustainability in integrated farming for future generations. Scientific research that addresses this important issue is still lacking. Therefore, this study was conducted to quantify the potential of tilapia pond sediment to supply $\mathrm{P}$ to morning glory (Ipomoea reptans), and the effects on the soil aggregate stability and the bulk density.

Morning glory (Ipomoea reptans) is an important leafy vegetable in south and southeast Asia [8]. It is popular in Thailand, Indonesia, Taiwan, Sri Lanka, Bangladesh, Vietnam and many regions of China. Geographically, it is known by different names such as kalmi in Bangladesh, kangkong in Sri Lanka, kanzon in Myanmar, rau muong in Vietnam, pukbung in Thailand and keng xin cai (empty heart) in China. This crop is intensively grown for both domestic consumption and marketing purposes. It is a short-duration crop that can be harvested even in 20 days. The vines of the crop can be used as fodder for cattle and pigs and also as feed for fish to meet their nutritional requirements. 
Although it is a short-duration crop, morning glory can take up high amounts of N, P and K. Therefore, morning glory was chosen as a potential crop in the study.

\section{MATERIALS AND METHODS}

\subsection{Site description}

The research was conducted in plots $\left(1 \times 1 \mathrm{~m}^{2}\right)$ on pond dikes during January to February 2005 at the Aquaculture and Aquatic Resources Management Farm of the Asian Institute of Technology (AIT), Bangkok, Thailand to determine the potential of tilapia pond sediment to supply $\mathrm{P}$ to morning glory, and the effects on soil aggregate stability and bulk density. The farm is located in the Central Plain of Thailand at $14^{\circ} 04^{\prime}$ North latitude and $100^{\circ} 37^{\prime}$ East longitude, with an elevation of $2.27 \mathrm{~m}$ above mean sea level. The Central Plain of Thailand has a tropical humid climate with two distinct seasons: wet and dry season. The soil in the experimental area is acid sulfate (Rangsit series), classified as Sulfic Tropaquepts. The color of the soil is black or dark gray with brown mottles and the structure of the soil is weak [9].

\subsection{Sediment collection and chemical analysis}

A tilapia pond, fertilized with inorganic fertilizers and fed for a period of 400 days, was drained and the sediment was collected from approximately $15 \mathrm{~cm}$ of the pond bottom and dried in the open air prior to using in morning glory culture. Plots were prepared on the pond dikes by plowing up to a depth of $15 \mathrm{~cm}$. Following the methods in [10] both sediment and plot soil samples were analyzed for $\mathrm{pH}$ (soil water ratio $1: 2.5), \mathrm{OM}$ (wet oxidation), total $\mathrm{N}$ (Kjeldahl), total $\mathrm{P}$ (acid digestion), available $\mathrm{P}$ (Olsen's) and available K (ammonium acetate extraction) prior to use for plot culture (Table 1). The available $\mathrm{N}$ was determined by the $\mathrm{KCl}$ extraction procedure followed by the Phenate method [11]. The silt content was determined by the hydrometer method [12]. It was calculated that the $P$ available with the application of $60 \mathrm{~kg}$ of sediment in a $1 \mathrm{~m}^{2}$ plot could meet the $P$ requirement of morning glory.

\subsection{Treatments}

There were six treatments, viz. zero input control without sediment $\left(\mathrm{S}_{0} \mathrm{~N}_{0} \mathrm{P}_{0} \mathrm{~K}_{0}\right)$, fertilizer control without sediment $\left(\mathrm{S}_{0} \mathrm{NPK}\right)$, sediment $60 \mathrm{~kg}$ without inorganic fertilizer $\left(\mathrm{S}_{60} \mathrm{~N}_{0} \mathrm{P}_{0} \mathrm{~K}_{0}\right)$, sediment $60 \mathrm{~kg}$ with balance $\mathrm{N}$ and $\mathrm{K}\left(\mathrm{S}_{60} \mathrm{NP}_{0} \mathrm{~K}\right)$, sediment $120 \mathrm{~kg}$ without inorganic fertilizer $\left(\mathrm{S}_{120} \mathrm{~N}_{0} \mathrm{P}_{0} \mathrm{~K}_{0}\right)$ and

Table 1: Nutrient status of sediment and farm soils.

\begin{tabular}{lcccccccc}
\hline $\begin{array}{l}\text { Potting } \\
\text { media }\end{array}$ & $\begin{array}{c}\mathrm{pH} \\
\left(\mathrm{g} \mathrm{kg}^{-1}\right)\end{array}$ & $\begin{array}{c}\mathrm{OM} \\
\left(\mathrm{g} \mathrm{kg}^{-1}\right)\end{array}$ & $\begin{array}{c}\mathrm{TN} \\
\left(\mathrm{g} \mathrm{kg}^{-1}\right)\end{array}$ & $\begin{array}{c}\mathrm{Av} \mathrm{N} \\
\left(\mathrm{g} \mathrm{kg}^{-1}\right)\end{array}$ & $\begin{array}{c}\mathrm{TP} \\
\left(\mathrm{mg} \mathrm{kg}^{-1}\right)\end{array}$ & $\begin{array}{c}\mathrm{Av} \mathrm{P} \\
\left(\mathrm{m} \mathrm{kg}^{-1}\right)\end{array}$ & $\begin{array}{c}\mathrm{Av} \mathrm{K} \\
\left(\mathrm{mg} \mathrm{kg}^{-1}\right)\end{array}$ & $\begin{array}{c}\text { Silt } \\
(\%)\end{array}$ \\
\hline Sediment & 6.0 & 29.0 & 2.14 & 0.20 & 170.0 & 147 & 80.0 & 27.0 \\
Plot soil & 5.0 & 16.5 & 1.01 & 0.10 & 31.0 & 19.0 & 57.0 & 17.0
\end{tabular}

OM, organic matter; TN, total nitrogen; Av N, available nitrogen; TP, total phosphorus;

Av P, available phosphorus; Av K, available potassium. 
sediment $120 \mathrm{~kg}$ with balance $\mathrm{N}$ and $\mathrm{K}\left(\mathrm{S}_{120} \mathrm{NP}_{0} \mathrm{~K}\right)$ with three replications following completely randomized design. Treatments with and without fertilizer were considered to determine the effects of its application on soil aggregates. Sediment 60 and $120 \mathrm{~kg} \mathrm{plot}^{-1}$ correspond to $30 \%$ and $60 \%$ of the plot soil by weight (weight of soil was $200 \mathrm{~kg} \mathrm{plot}^{-1}$ in $0-15 \mathrm{~cm}$ depth). Therefore, 60 and $120 \mathrm{~kg}$ of the plot soil was removed from each plot of the respective treatment and replaced with the same amount of sediment, and then the sediment and the plot soil were mixed well.

\subsection{Fertilizer application and seed sowing}

The nitrogen, $\mathrm{P}$ and $\mathrm{K}$ requirements of morning glory tissue were $21.47,5.65$ and $27.11 \mathrm{~g} \mathrm{plot}^{-1}$, respectively [13]. Considering 50\% recovery of both $\mathrm{N}$ and $\mathrm{P}$ [14], and $60 \%$ of $\mathrm{K}$ [15], inorganic fertilizers supplemented the balance N, P and $\mathrm{K}$ in the respective plots as per eqn (1) [16]. Of the total N, 50\% was applied at seeding, and the balance was supplied 15 days after seeding. Phosphorus and $\mathrm{K}$ were applied as a single dose at seeding. Seeds at the rate of $20 \mathrm{~g} \mathrm{~m}^{-2}$ were broadcasted in rows with a row-to-row spacing of $10 \mathrm{~cm}$. The plots were watered every day until two weeks, and then every alternate day.

\subsection{Harvesting of morning glory and its nutrient analysis}

The crop was harvested in 25 days after seed sowing and the weight of all the plants per plot, including the roots, was recorded. Plant samples (roots and edible parts together) were analyzed for $\mathrm{N}$ [10], $\mathrm{P}$ and $\mathrm{K}$ [17]. The nitrate content in the edible parts $\left(\mathrm{NO}_{3}^{-}-\mathrm{N}\right)$ was determined by the aqueous extraction method followed by the addition of Nitra Ver [18]. After harvesting the crop, soil from the plots was collected to determine the residual nutrients, the water-stable soil aggregates of $<2 \mathrm{~mm}$ but $>1 \mathrm{~mm}$ in size [19] and the bulk density [20].

$$
N r=(N c-N s \times R F s) / R F f
$$

where,

$N r=$ nutrient to be applied $\left(\mathrm{g}\right.$ plot $\left.^{-1}\right)$

$N c=$ nutrient requirements of morning glory tissue $\left(\mathrm{g} \mathrm{plot}^{-1}\right)$

$N s=$ available nutrient in the sediment and or the soil $\left(\mathrm{g} \mathrm{plot}^{-1}\right)$

$R F s=$ nutrient recover fraction from the soil

$R F f=$ nutrient recover fraction from the fertilizer

\subsection{Statistical analysis}

Data analysis was performed using one-way ANOVA, treatment means were compared using Fisher's protected LSD test and the differences were considered significant at $\mathrm{P}=0.05$. SPSS (version 10.0) was used for data analysis.

\section{RESULTS AND DISCUSSION}

\subsection{Total biomass}

The total biomass (fresh and dry matter) of morning glory was significantly higher in all the treatments when compared to the zero input control (Table 2 ). The fresh yield was increased by $82 \%$ from the zero input control $\left(\mathrm{S}_{0} \mathrm{~N}_{0} \mathrm{P}_{0} \mathrm{~K}_{0}\right)$ to the treatment $\mathrm{S}_{60} \mathrm{~N}_{0} \mathrm{P}_{0} \mathrm{~K}_{0}$ (30\% sediment without inorganic fertilizer); 
Table 2: Total biomass production, $\mathrm{N} / \mathrm{P}$ ratio and $\mathrm{NO}_{3}^{-}-\mathrm{N}$ content in morning glory (mean $\pm \mathrm{SD}$ ).

\begin{tabular}{lcccc}
\hline & \multicolumn{2}{c}{ Total biomass } & & \\
\cline { 2 - 3 } Treatment & Fresh matter $\left(\mathrm{kg} \mathrm{plot}^{-1}\right)$ & Dry matter $\left(\mathrm{g} \mathrm{plot}^{-1}\right)$ & $\begin{array}{c}\text { N ratio } \\
\left(\mathrm{mg} \mathrm{kg}^{-1}\right)\end{array}$ & $\begin{array}{c}\mathrm{NO}_{3}^{-}-\mathrm{N} \text { Content } \\
\left(\mathrm{mg} \mathrm{kg}^{-1} \mathrm{FWE}\right)\end{array}$ \\
\hline $\mathrm{S}_{0} \mathrm{~N}_{0} \mathrm{P}_{0} \mathrm{~K}_{0}$ & $2.8 \pm 0.74^{\mathrm{a}}$ & $304.4 \pm 111.74^{\mathrm{a}}$ & $7.4 \pm 1.56^{\mathrm{a}}$ & $157.7 \pm 4.93^{\mathrm{a}}$ \\
$\mathrm{S}_{0} \mathrm{NPK}^{\mathrm{c}}$ & $7.4 \pm 0.81^{\mathrm{c}}$ & $804.1 \pm 85.83^{\mathrm{c}}$ & $8.3 \pm 0.90^{\mathrm{a}}$ & $242.0 \pm 9.85^{\mathrm{b}}$ \\
$\mathrm{S}_{60} \mathrm{~N}_{0} \mathrm{P}_{0} \mathrm{~K}_{0}$ & $5.1 \pm 0.25^{\mathrm{b}}$ & $486.3 \pm 35.03^{\mathrm{b}}$ & $4.7 \pm 2.02^{\mathrm{b}}$ & $174.7 \pm 5.03^{\mathrm{ac}}$ \\
$\mathrm{S}_{60} \mathrm{NP}_{0} \mathrm{~K}$ & $7.5 \pm 0.46^{\mathrm{c}}$ & $801.2 \pm 50.31^{\mathrm{c}}$ & $8.2 \pm 1.54^{\mathrm{a}}$ & $238.6 \pm 13.87^{\mathrm{b}}$ \\
$\mathrm{S}_{120} \mathrm{~N}_{0} \mathrm{P}_{0} \mathrm{~K}_{0}$ & $5.8 \pm 0.21^{\mathrm{b}}$ & $608.5 \pm 70.24^{\mathrm{b}}$ & $6.8 \pm 1.43^{\mathrm{a}}$ & $190.3 \pm 10.02^{\mathrm{c}}$ \\
$\mathrm{S}_{120} \mathrm{NP}_{0} \mathrm{~K}$ & $7.9 \pm 0.20^{\mathrm{c}}$ & $849.6 \pm 48.15^{\mathrm{c}}$ & $8.2 \pm 0.41^{\mathrm{a}}$ & $254.0 \pm 12.77^{\mathrm{b}}$ \\
$\mathrm{LSD}_{(0.05)}$ & 0.90 & 127.60 & 2.51 & 20.53 \\
\hline
\end{tabular}

FWE, Fresh weight of edible parts; different superscript letters indicate significant differences among the values within the same column.

while the increment was $168 \%$ in the treatment $\mathrm{S}_{60} \mathrm{NP}_{0} \mathrm{~K}$ (30\% sediment with the balance $\mathrm{N}$ and $\mathrm{K}$ fertilizer). Similar trends were also observed in the case of dry matter yields. The results explained the importance of $\mathrm{N}$ and $\mathrm{K}$ supplementation by inorganic fertilizers to get good yields of morning glory using fishpond sediment as a source of P. However, when N, P and K were sufficient, the difference in the biomass production in the treatments $\mathrm{S}_{0} \mathrm{NPK}, \mathrm{S}_{60} \mathrm{NP}_{0} \mathrm{~K}$ and $\mathrm{S}_{120} \mathrm{NP}_{0} \mathrm{~K}$ was insignificant. The insignificant increment of biomass production from the treatment $\mathrm{S}_{60} \mathrm{NP}_{0} \mathrm{~K}$ to $\mathrm{S}_{120} \mathrm{NP}_{0} \mathrm{~K}$ suggests not using $60 \%$ sediment for morning glory production. Sediment removal from fishpond and its application to agricultural fields are labor intensive, therefore, an application of $60 \%$ sediment to farm soils will increase labor costs and also the excess amount of $\mathrm{P}$ in the sediment will remain unutilized. This additional $\mathrm{P}$ could be a source of environmental pollution, like eutrophication, in the surface water. Therefore, the application of $30 \%$ sediment to the farm soil would be sufficient considering better yields of morning glory and efficient utilization of $\mathrm{P}$ embedded in the sediment. The fresh yield of morning glory in the $\mathrm{S}_{60} \mathrm{NP}_{0} \mathrm{~K}$ treatment was $7.5 \mathrm{~kg} \mathrm{~m}^{-2}$ land area with a density of 420 plants $\mathrm{m}^{-2}$, which was equivalent to $75 \mathrm{tha}^{-1} \mathrm{crop}^{-1}$. According to Siemonsma and Piluek [8], a fresh weight of 7-30 $\mathrm{tha}^{-1}$ crop $^{-1}$ with a plant density of 30-170 plants $\mathrm{m}^{-2}$ of morning glory should be produced. Therefore, the current yield level agrees with the field level production figures.

\section{$3.2 \mathrm{~N}$ uptake and residual}

The uptake and recovery of $\mathrm{N}$ were significantly higher in all the treatments when compared to the control, with the exception that the difference of $\mathrm{N}$ uptake between the control and the treatment $\mathrm{S}_{60} \mathrm{~N}_{0} \mathrm{P}_{0} \mathrm{~K}_{0}$ was insignificant (Table 3). However, the uptake and recovery were significantly higher in the treatment $\mathrm{S}_{120} \mathrm{NP}_{0} \mathrm{~K}$ than in $\mathrm{S}_{0} \mathrm{NPK}$, while these values in these two treatments were insignificant compared with $\mathrm{S}_{60} \mathrm{NP}_{0} \mathrm{~K}$, though the amount of available $\mathrm{N}$ in these three treatments was same $\left(45.9 \mathrm{~g} \mathrm{plot}^{-1}\right)$. This is attributed to a higher amount of available $\mathrm{P}$ in the treatment $\mathrm{S}_{120} \mathrm{NP}_{0} \mathrm{~K}$.

The sediment contained higher amounts of OM, N, P and $\mathrm{K}$ as compared to farm soils (Table 1). Due to the microbial breakdown of $\mathrm{OM}$, more $\mathrm{N}$ becomes available [21]. Nitrogen accelerates the activity of nitrate reductase enzyme in soil [22], which reduces $\mathrm{NO}_{3}^{-}-\mathrm{N}$ to $\mathrm{NO}_{2}^{-}-\mathrm{N}$, and then to $\mathrm{NH}_{4}^{+}-\mathrm{N}$, and then incorporates into amino acids at the end [23]. The nitrate reductase enzyme 
Table 3: Nitrogen $(\mathrm{N})$ uptake and its recovery by morning glory and $\mathrm{N}$ remaining in the soil as residue after the harvest of the crop.

\begin{tabular}{|c|c|c|c|c|c|c|c|c|}
\hline \multirow[b]{2}{*}{ Treatment } & \multicolumn{5}{|c|}{$\mathrm{N}$ inputs $\left(\mathrm{g} \mathrm{plot}^{-1}\right)$} & \multirow{2}{*}{$\begin{array}{c}\text { Uptake } \\
\left(\mathrm{g} \mathrm{plot}^{-1}\right)\end{array}$} & \multirow{2}{*}{$\begin{array}{c}\text { Recovery } \\
(\%)\end{array}$} & \multirow{2}{*}{$\begin{array}{c}\text { Residual } \\
\left(\mathrm{g} \mathrm{plot}^{-1}\right)\end{array}$} \\
\hline & Soil & Sed & Fert & Water & Total & & & \\
\hline $\mathrm{S}_{0} \mathrm{~N}_{0} \mathrm{P}_{0} \mathrm{~K}_{0}$ & 20.0 & 0.0 & 0.0 & 3.0 & 23.0 & $3.3 \pm 0.41^{\mathrm{a}}$ & $14.3 \pm 1.79^{\mathrm{a}}$ & $12.1 \pm 0.55^{\mathrm{a}}$ \\
\hline $\mathrm{S}_{0} \mathrm{NPK}$ & 20.0 & 0.0 & 22.9 & 3.0 & 45.9 & $16.4 \pm 2.14^{\mathrm{bc}}$ & $35.7 \pm 4.67^{\mathrm{bc}}$ & $22.6 \pm 1.87^{\mathrm{c}}$ \\
\hline $\mathrm{S}_{60} \mathrm{~N}_{0} \mathrm{P}_{0} \mathrm{~K}_{0}$ & 14.0 & 12.0 & 0.0 & 3.0 & 29.0 & $7.3 \pm 3.57^{\mathrm{a}}$ & $25.1 \pm 12.33^{\mathrm{b}}$ & $13.1 \pm 3.74^{\mathrm{a}}$ \\
\hline $\mathrm{S}_{60} \mathrm{NP}_{0} \mathrm{~K}$ & 14.0 & 12.0 & 16.9 & 3.0 & 45.9 & $20.1 \pm 3.67^{\mathrm{cd}}$ & $43.7 \pm 8.00^{\mathrm{cd}}$ & $18.1 \pm 3.32^{\mathrm{b}}$ \\
\hline $\mathrm{S}_{120} \mathrm{~N}_{0} \mathrm{P}_{0} \mathrm{~K}_{0}$ & 8.0 & 24.0 & 0.0 & 3.0 & 35.0 & $12.7 \pm 2.40^{\mathrm{b}}$ & $36.4 \pm 6.85^{\mathrm{bc}}$ & $13.5 \pm 1.69^{\mathrm{a}}$ \\
\hline $\mathrm{S}_{120} \mathrm{NP}_{0} \mathrm{~K}$ & 8.0 & 24.0 & 10.9 & 3.0 & 45.9 & $23.3 \pm 0.81^{\mathrm{d}}$ & $50.6 \pm 1.77^{\mathrm{d}}$ & $14.2 \pm 1.50^{\mathrm{ab}}$ \\
\hline $\operatorname{LSD}_{(0.05)}$ & & & & & & 4.44 & 12.39 & 4.23 \\
\hline
\end{tabular}

Sed, sediment; Fert, fertilizer; different superscript letters indicate significant differences among the values within the same column.

requires $\mathrm{P}$, in addition to molybdenum and NADPH, for its function [24]. Therefore, in the presence of a high amount of $\mathrm{P}$, the uptake and recovery of $\mathrm{N}$ by plants will be higher [25]. This is reflected in the residual $\mathrm{N}$ in the $\mathrm{S}_{0} \mathrm{NPK}$ treatment, which is significantly the highest among the others (Table 3). Roostalu et al. [26] found 51-57\% recovery of the available $\mathrm{N}$ in the soil on an average, while Prasad and Power [27] reported values ranging from 20 to 80\%, which endorse the findings.

The treatments had significant effects on the nitrate content in the fresh edible parts of morning glory, where the maximum level was $254 \mathrm{mg} \mathrm{kg}^{-1}$ (Table 2). The $\mathrm{NO}_{3}^{-}-\mathrm{N}$ content in leafy vegetables is a major concern for human health [28]. The guide value of nitrate level in morning glory is not available. The maximum tolerable nitrate concentrations in lettuce and spinach are 3000 and $2000 \mathrm{mg} \mathrm{kg}^{-1}$ of fresh materials, respectively [29]. Therefore, morning glory grown using tilapia pond sediment in the current study would be safe for human consumption.

\subsection{P uptake and residual}

The uptake of $\mathrm{P}$ by morning glory in the treatment $\mathrm{S}_{0} \mathrm{NPK}$ was significantly lower than in the treatments $\mathrm{S}_{60} \mathrm{NP}_{0} \mathrm{~K}$ and $\mathrm{S}_{120} \mathrm{NP}_{0} \mathrm{~K}$, while no significant difference was found between $\mathrm{S}_{60} \mathrm{NP}_{0} \mathrm{~K}$ and $\mathrm{S}_{120} \mathrm{NP}_{0} \mathrm{~K}$ (Table 4). Phosphorus uptake and recovery were different among the treatments due to the variation in the total and the available $\mathrm{P}$ and $\mathrm{N}$, and the $\mathrm{pH}$ in the sediment and farm soils. At a low $\mathrm{pH}$, phosphate ions form complex compounds, with $\mathrm{Fe}$ and $\mathrm{Al}$, and precipitates, which are not available to the crops readily [30]. Therefore, the $\mathrm{P}$ uptake was significantly lower in $\mathrm{S}_{0} \mathrm{NPK}$ than in $\mathrm{S}_{60} \mathrm{NP}_{0} \mathrm{~K}$ and $\mathrm{S}_{120} \mathrm{NP}_{0} \mathrm{~K}$. In the treatments $\mathrm{S}_{0} \mathrm{NPK}$ and $\mathrm{S}_{60} \mathrm{NP}_{0} \mathrm{~K}$, the supply of $\mathrm{N}, \mathrm{P}$ and $\mathrm{K}$ was balanced, and hence there was no significant difference in the N, $\mathrm{P}$ and $\mathrm{K}$ recoveries between these two treatments; while in the treatment $\mathrm{S}_{120} \mathrm{NP}_{0} \mathrm{~K}$ there was an additional amount of $\mathrm{P}$ in plot soils, and hence its recovery was significantly lower than in the treatment $\mathrm{S}_{60} \mathrm{NP}_{0} \mathrm{~K}$.

The residual $\mathrm{P}$ in the plot soils in treatments $\mathrm{S}_{120} \mathrm{~N}_{0} \mathrm{P}_{0} \mathrm{~K}_{0}$ and $\mathrm{S}_{120} \mathrm{NP}_{0} \mathrm{~K}$ was higher than the amount required for morning glory and significantly higher compared to other treatments, revealing that if $60 \%$ of sediment is used in farm soils, morning glory could be grown a second time without supplementation with an inorganic phosphate fertilizer. The recovery of $\mathrm{P}$ in the fertilizer is usually 
Table 4: Phosphorus (P) uptake and its recovery by morning glory and P remaining in the soil as residue after the crop harvest.

\begin{tabular}{|c|c|c|c|c|c|c|c|c|}
\hline \multirow[b]{2}{*}{ Treatment } & \multicolumn{5}{|c|}{$\mathrm{N}$ inputs $\left(\mathrm{g} \mathrm{plot}^{-1}\right)$} & \multirow{2}{*}{$\begin{array}{l}\text { Uptake } \\
\left(\mathrm{g} \mathrm{plot}^{-1}\right)\end{array}$} & \multirow{2}{*}{$\begin{array}{c}\text { Recovery } \\
(\%)\end{array}$} & \multirow{2}{*}{$\begin{array}{l}\text { Residual } \\
\left(\mathrm{g} \mathrm{plot}^{-1}\right)\end{array}$} \\
\hline & Soil & Sed & Fert & Water & Total & & & \\
\hline $\mathrm{S}_{0} \mathrm{~N}_{0} \mathrm{P}_{0} \mathrm{~K}_{0}$ & 3.8 & 0.0 & 0.0 & 0.05 & 3.8 & $0.5 \pm 0.14^{\mathrm{a}}$ & $12.0 \pm 3.58^{\mathrm{ab}}$ & $2.6 \pm 0.51^{\mathrm{a}}$ \\
\hline $\mathrm{S}_{0} \mathrm{NPK}$ & 3.8 & 0.0 & 7.6 & 0.05 & 11.5 & $2.0 \pm 0.37^{\mathrm{c}}$ & $17.6 \pm 3.25^{\mathrm{cd}}$ & $8.1 \pm 0.26^{b c}$ \\
\hline $\mathrm{S}_{60} \mathrm{~N}_{0} \mathrm{P}_{0} \mathrm{~K}_{0}$ & 2.7 & 8.8 & 0.0 & 0.05 & 11.5 & $1.5 \pm 0.10^{\mathrm{b}}$ & $13.1 \pm 0.85^{\mathrm{ab}}$ & $8.8 \pm 0.32^{\mathrm{c}}$ \\
\hline $\mathrm{S}_{60} \mathrm{NP}_{0} \mathrm{~K}$ & 2.7 & 8.8 & 0.0 & 0.05 & 11.5 & $2.5 \pm 0.11^{\mathrm{d}}$ & $21.3 \pm 1.00^{\mathrm{d}}$ & $7.8 \pm 0.25^{\mathrm{b}}$ \\
\hline $\mathrm{S}_{120} \mathrm{~N}_{0} \mathrm{P}_{0} \mathrm{~K}_{0}$ & 1.4 & 17.6 & 0.0 & 0.05 & 19.1 & $1.9 \pm 0.26^{\mathrm{bc}}$ & $9.9 \pm 1.33^{\mathrm{a}}$ & $15.5 \pm 0.50^{\mathrm{d}}$ \\
\hline $\mathrm{S}_{120} \mathrm{NP}_{0} \mathrm{~K}$ & 1.4 & 17.6 & 0.0 & 0.05 & 19.1 & $2.8 \pm 0.24^{\mathrm{d}}$ & $14.8 \pm 1.24^{\mathrm{bc}}$ & $14.8 \pm 0.72^{\mathrm{d}}$ \\
\hline $\operatorname{LSD}_{(0.05)}$ & & & & & & 0.40 & 3.87 & 0.82 \\
\hline
\end{tabular}

Sed, sediment; Fert, fertilizer; different superscript letters indicate significant differences among the values within the same column.

$10-30 \%$ [15], which can be increased up to $56 \%$ or above with better crop management [14]. The $\mathrm{P}$ recovery in the treatment $\mathrm{S}_{60} \mathrm{NP}_{0} \mathrm{~K}$ was $21.3 \%$, which satisfied the normal recovery range of most of the field crops.

Generally, the rate of $\mathrm{NO}_{3}^{-}$uptake by plants in most agricultural soil is high and, in that case, there is an increase in the anion synthesis within the plant coupled with a corresponding increase in the accumulation of $\mathrm{Ca}^{2+}, \mathrm{Mg}^{2+}$ and $\mathrm{K}^{+}$, and then $\mathrm{OH}^{-}$and $\mathrm{HCO}_{3}^{-}$may be released from the roots of the plants to the soil [21]. This increases the $\mathrm{pH}$ in the rhizosphere, and hence promotes $\mathrm{P}$ availability, which in turn, might influence the $\mathrm{P}$ uptake by the plants. According to Havlin et al. [21] N promotes P uptake by plants by improving the growth of the shoot and the root, altering the plant metabolism, and increasing the solubility and availability of $\mathrm{P}$. These conditions increase the uptake of both $\mathrm{N}$ and $\mathrm{P}$ by plants through their combined effects [25].

The N/P ratio was significantly lowest in the treatment $\mathrm{S}_{60} \mathrm{~N}_{0} \mathrm{P}_{0} \mathrm{~K}_{0}$ because of an overly low $\mathrm{N}$ availability in the soil and hence $\mathrm{N}$ uptake by morning glory; while the difference among the other treatments was insignificant (Table 2). In plants, the concentrations of $\mathrm{N}$ and $\mathrm{P}$ are strongly correlated [31], while the N/P ratio in crops is generally considered to average 8 [32]. The N/P ratio in the treatments, $\mathrm{S}_{0} \mathrm{NPK}, \mathrm{S}_{60} \mathrm{NP}_{0} \mathrm{~K}$ and $\mathrm{S}_{120} \mathrm{NP}_{0} \mathrm{~K}$, confirmed the presence of an amount of $\mathrm{P}$ in plot soils required for the normal growth and development of morning glory.

\section{4 $\mathrm{K}$ uptake and residual}

Potassium uptake was significantly higher in all the treatments when compared to the control except the difference of $\mathrm{K}$ uptake between the control and the treatment $\mathrm{S}_{60} \mathrm{~N}_{0} \mathrm{P}_{0} \mathrm{~K}_{0}$, which was insignificant (Table 5). However, $\mathrm{K}$ uptake significantly increased from the treatment $\mathrm{S}_{0} \mathrm{NPK}$ to $\mathrm{S}_{60} \mathrm{NP}_{0} \mathrm{~K}$ and from $\mathrm{S}_{60} \mathrm{NP}_{0} \mathrm{~K}$ to $\mathrm{S}_{120} \mathrm{NP}_{0} \mathrm{~K}$. This might be the cause of the higher levels of $\mathrm{N}$ availability in the corresponding treatments. The nitrogen content in the soil may increase $\mathrm{K}$ uptake by morning glory, since increase in the $\mathrm{NH}_{4}^{+}$ions releases the fixed $\mathrm{K}^{+}$ions in $2: 1$ clays to soil solution thereby favoring the uptake of $\mathrm{K}$ [33].

Nitrogen enhances vegetative growth indicating absorption of higher amounts of $\mathrm{K}$, if it is sufficient in the soil. Higher K uptake is reflected with $\mathrm{K}$ recovery by morning glory and residual in soils; higher 
Table 5: Potassium (K) uptake and its recovery by morning glory and $\mathrm{K}$ remaining in the soil as residue after crop harvest.

\begin{tabular}{|c|c|c|c|c|c|c|c|c|}
\hline \multirow[b]{2}{*}{ Treatment } & \multicolumn{5}{|c|}{$\mathrm{K}$ inputs (g plot $\left.{ }^{-1}\right)$} & \multirow{2}{*}{$\begin{array}{c}\text { Uptake } \\
\left(\mathrm{g} \mathrm{plot}^{-1}\right)\end{array}$} & \multirow{2}{*}{$\begin{array}{c}\text { Recovery } \\
(\%)\end{array}$} & \multirow{2}{*}{$\begin{array}{l}\text { Residual } \\
\left(\mathrm{g} \mathrm{plot}^{-1}\right)\end{array}$} \\
\hline & Soil & Sed & Fert & Water & Total & & & \\
\hline $\mathrm{S}_{0} \mathrm{~N}_{0} \mathrm{P}_{0} \mathrm{~K}_{0}$ & 11.4 & 0.0 & 0.0 & 1.0 & 12.4 & $4.1 \pm 0.74^{\mathrm{a}}$ & $32.8 \pm 5.96^{\mathrm{a}}$ & $6.5 \pm 0.78^{\mathrm{a}}$ \\
\hline $\mathrm{S}_{0} \mathrm{NPK}$ & 11.4 & 0.0 & 33.8 & 1.0 & 46.2 & $16.7 \pm 1.89^{c}$ & $36.3 \pm 4.10^{\mathrm{ab}}$ & $27.3 \pm 2.08^{\mathrm{d}}$ \\
\hline $\mathrm{S}_{60} \mathrm{~N}_{0} \mathrm{P}_{0} \mathrm{~K}_{0}$ & 8.0 & 4.8 & 0.0 & 1.0 & 13.8 & $5.6 \pm 0.50^{\mathrm{ab}}$ & $40.5 \pm 3.66^{\mathrm{bc}}$ & $6.3 \pm 0.60^{\mathrm{a}}$ \\
\hline $\mathrm{S}_{60} \mathrm{NP}_{0} \mathrm{~K}$ & 8.0 & 4.8 & 32.4 & 1.0 & 46.2 & $19.7 \pm 0.92^{\mathrm{d}}$ & $42.7 \pm 2.00^{\mathrm{bc}}$ & $24.5 \pm 1.31^{\mathrm{c}}$ \\
\hline $\mathrm{S}_{120} \mathrm{~N}_{0} \mathrm{P}_{0} \mathrm{~K}_{0}$ & 4.6 & 9.6 & 0.0 & 1.0 & 15.2 & $7.0 \pm 0.65^{\mathrm{b}}$ & $46.0 \pm 4.28^{\mathrm{cd}}$ & $6.0 \pm 0.53^{\mathrm{a}}$ \\
\hline $\mathrm{S}_{120} \mathrm{NP}_{0} \mathrm{~K}$ & 4.6 & 9.6 & 16.2 & 1.0 & 46.2 & $23.2 \pm 1.19^{\mathrm{e}}$ & $50.1 \pm 2.57^{\mathrm{d}}$ & $20.6 \pm 1.44^{b}$ \\
\hline $\operatorname{LSD}_{(0.05)}$ & & & & & & 1.93 & 7.06 & 2.22 \\
\hline
\end{tabular}

Sed, sediment; Fert, fertilizer; different superscript letters indicate significant differences among the values within the same column.

Table 6: Water-stable soil aggregates (WSA) and bulk density $\left(\mathrm{D}_{\mathrm{b}}\right)$ of the farm soils under different treatments (mean $\pm \mathrm{SD}$ ).

\begin{tabular}{lcc}
\hline Treatment & WSA $\left(\mathrm{g} \mathrm{kg}^{-1}\right)$ & $\mathrm{D}_{\mathrm{b}}\left(\mathrm{g} \mathrm{cc}^{-1}\right)$ \\
\hline $\mathrm{S}_{0} \mathrm{~N}_{0} \mathrm{P}_{0} \mathrm{~K}_{0}$ & $192 \pm 9.69^{\mathrm{a}}$ & $1.33 \pm 0.12^{\mathrm{a}}$ \\
$\mathrm{S}_{0} \mathrm{NPK}$ & $203 \pm 12.59^{\mathrm{a}}$ & $1.33 \pm 0.06^{\mathrm{a}}$ \\
$\mathrm{S}_{60} \mathrm{~N}_{0} \mathrm{P}_{0} \mathrm{~K}_{0}$ & $264 \pm 42.98^{\mathrm{b}}$ & $1.16 \pm 0.06^{\mathrm{bc}}$ \\
$\mathrm{S}_{60} \mathrm{NP}_{0} \mathrm{~K}$ & $299 \pm 16.31^{\mathrm{b}}$ & $1.16 \pm 0.11^{\mathrm{bc}}$ \\
$\mathrm{S}_{120} \mathrm{~N}_{0} \mathrm{P}_{0} \mathrm{~K}_{0}$ & $406 \pm 24.59^{\mathrm{c}}$ & $1.10 \pm 0.10^{\mathrm{c}}$ \\
$\mathrm{S}_{120} \mathrm{NP}_{0} \mathrm{~K}$ & $394 \pm 33.38^{\mathrm{c}}$ & $1.13 \pm 0.06^{\mathrm{c}}$ \\
$\mathrm{LSD}_{(0.05)}$ & 46.42 & 0.15
\end{tabular}

Different superscript letters indicate significant differences among the values within the same column.

the recovery, lower is the residual. Roberts [15] found that the K recovery by the crop to be 50-60\%, which may vary depending on the crop management practices, crop and soil characteristics and others.

\subsection{Water-stable soil aggregates and bulk density}

The water-stable soil aggregates increased and the bulk density decreased with the application of an increased amount of sediment to farm soil (Table 6). The soil aggregate stability increased by $56 \%$ and the bulk density decreased by $13 \%$ from the treatment zero input control $\left(\mathrm{S}_{0} \mathrm{~N}_{0} \mathrm{P}_{0} \mathrm{~K}_{0}\right)$ to the treatment $\mathrm{S}_{60} \mathrm{NP}_{0} \mathrm{~K}$. The effect of inorganic fertilizer application on either the aggregate stability or the bulk density was insignificant. Aggregation depends on the soil physical, chemical and biological phenomena of OM, clay and fine silt particles [34]. High aggregation has been reported in soil with high $\mathrm{P}$ retention due to high levels of $\mathrm{Fe}$ and $\mathrm{Al}$ [35] and calcium carbonate [36]. The sediment contained higher levels of $\mathrm{P}, \mathrm{OM}$, silt fractions (Table 1), and $\mathrm{Ca}$ since $\mathrm{CaCO}_{3}$ was applied to the ponds at a rate of $1 \mathrm{~kg} \mathrm{~m}^{-2}$, and hence the sediment's potential to improve soil aggregates. 
High bulk density creates agronomic problems in many of the cultivated soil [37]. Our farm soil was clay. The bulk density of clay soil is extremely variable and a value of $1.3 \mathrm{~g} \mathrm{cc}^{-1}$ or above is not suitable for the development of the root. [30]. As OM is beneficial for the formation of soil aggregates [38], an application of pond sediment containing higher levels of OM causes a relatively loose structure in the surface layer of the field soil and thus the sediment has the potential to decrease the bulk density of the soil to favorable levels.

\subsection{Heavy metal issue of using fishpond sediment in agriculture}

Heavy metals are highly toxic, bio-accumulative and persistent, therefore, their cycling in nature is a serious environmental and human health problem [39]. The build-up of heavy metals in sediments have been reported in many places of the world and their reuse, such as in agriculture, can potentially threaten the health of animals including humans [40, 41]. However, the accumulation of heavy metals in freshwater fishponds depends on the characteristics of the site and mainly on pond inputs such as fertilizers, organic matter and fish feeds. In the current study, the sediment collected from tilapia ponds fertilized with urea, triple super phosphate fertilizer (TSP) and pelleted feed was used for morning glory culture. The inputs applied to ponds were almost free from heavy metals like cadmium $(\mathrm{Cd})$ and arsenic (As). The Cd content in urea is very low, but in TSP it is $100 \mathrm{mg} \mathrm{kg}^{-1}$ [42]; while As content in urea is negligible, but in TSP it is $18 \mathrm{mg} \mathrm{kg}^{-1} \mathrm{P}$ [43]. About $7 \mathrm{~kg}$ of P was applied in a $200 \mathrm{~m}^{2}$ fishpond in a 12-month culture period. Therefore, a negligible amount of $\mathrm{As}$ and $\mathrm{Cd}$ was added in the fishpond, and hence minimizing the chances of accumulation in the sediment and consequently in morning glory. However, heavy metal accumulation in the pond sediment and thereby in the food chain should be taken into consideration intensively if such integrated studies are conducted in the contaminated areas.

\section{CONCLUSIONS}

Tilapia pond sediment was successfully used as a source of $\mathrm{P}$ fertilizer for morning glory and as a soil conditioner to improve the physical properties of the soil, such as the aggregate stability and the bulk density. With the supplementation of $\mathrm{N}$ and $\mathrm{K}$ by inorganic fertilizers and an application of 30\% fishpond sediment, together with the inherent soil $\mathrm{P}$, provided the required amount of $\mathrm{P}$ for the better growth and development of morning glory, where the contribution of the sediment for $\mathrm{P}$ supplementation was $76 \%$. Inorganic fertilizers mainly supported $\mathrm{N}$ and $\mathrm{K}$, where the contribution of the sediment to the total nutrient inputs in the case of $\mathrm{N}$ was $26 \%$ and in the case of $\mathrm{K}$ was only $10 \%$ in the treatment $\mathrm{S}_{60} \mathrm{NP}_{0} \mathrm{~K}$.

The study contributed in the efficient utilization of nutrients embedded in the sediment and improvement of soil structure of farm soils, thus reducing nutrient losses and possibilities of soil erosion. Good soil structure influences water retention, resistance to erosion, nutrient availability and ultimately crop growth and development, thus sustains long-term crop productivity. This kind of interdisciplinary research is needed for environmentally sound and sustainable aquaculture-agriculture technologies, which could eventually provide multitudes of benefits not only to resource-poor fish farmers, but also to the consuming sectors and the overall environment.

\section{ACKNOWLEDGMENTS}

We gratefully acknowledge the European Commission funded Pond Live Project (Proposal No: ICA42000-20034) and the Asian Institute of Technology for supporting this research study. 


\section{REFERENCES}

[1] Stickney, R.R., Principles of Aquaculture, John Wiley \& Sons Inc: New York, 1994.

[2] Jamu, D.M. \& Piedrahita, R.H., Ten-year simulations of organic matter concentrations in tropical aquaculture ponds using multiple pool modeling approach. Aquacultural Engineering, 25, pp. 187-201, 2001.

[3] NACA, Introduction of Chinese integrated fish farming and its major models. Training Manual: Integrated Fish Farming in China, Network of Aquaculture Centers in Asia, Bangkok, Thailand, NACA/TR/85/11, 1985.

[4] Rahman, M.M., Yakupitiyage, A. \& Ranamukhaarachchi, S.L., Agricultural use of fishpond sediment for environmental amelioration. Thammasat International Journal of Science and Technology, 9(4), pp. 1-10, 2004.

[5] Eynard, A., Schumacher, T.E., Lindstorm, M.J. \& Malo, D.D., Aggregate sizes and stability in cultivated South Dakota Prairie Ustolls and Usterts. Soil Science Society of America Journal, 68, pp. 1360-1365, 2004.

[6] Tchienkoua \& Zech, W., Chemical and spectral characterization of soil phosphorus under three land uses from an Andic Palehumult in West Cameroon. Agriculture Ecosystems and Environment, 100, pp. 193-200, 2003.

[7] Tan, Z.X., Lal, R. \& WIebe, K.D., Global soil nutrient depletion and yield reduction. Journal of Sustainable Agriculture, 26(1), pp. 123-145, 2005.

[8] Siemonsma, J.S. \& Piluek, K. (eds.), Plant Resources of South-East Asia, No. 8, Vegetables, PROSEA: Bogor, Indonesia, pp. 181-184, 1994.

[9] Pradhan, B., Establishment and management of Leucanea spp. and Gliricidia spp. as fodder trees on an acid sulfate soils. AIT Thesis no. AE-90-41, 1990.

[10] Page, A.L., Miller, R.H. \& Keeney, D.R. (eds.), Methods of Soil Analysis. Part 2. Chemical and Microbiological Properties, American Society of Agronomy Inc: Madison, WI, 1982.

[11] APHA, Standards Methods for the Examination of Water and Wastewater, 16th edn, American Public Health Association, Washington, DC, 1985.

[12] Gee, G.W. \& Bauder, J.W., Particle size analysis, Methods of Soil Analysis. Part 1. Physical and Mineralogical Methods, ed. K. Arnold, American Society of Agronomy Inc: Madison, WI, USA, pp. 383-411, 1986.

[13] Rahman, M.M., Yakupitiyage, A. \& Ranamukhaarachchi, S.L., Fertilizer requirements of morning glory. Asia Pacific Journal of Rural Development, 2005, in press.

[14] Sharpley, A., Fate and transport of nutrients: phosphorus, United States Department of Agriculture, Natural Resources Conservation Service, Working paper no. 8, 1995.

[15] Roberts, T.L., Maximum fertilizer efficiency in zero tillage, Manitoba - North Dakota Zero Tillage Workshop, Brandon, Manitoba, January 23-25, 1995.

[16] Angus, J.F., Modelling N Fertilization requirements for crops and pastures. Nitrogen Fertilization in the Environment ed. P.E. Bacon, Marcel Dekker Inc: New York, pp. 109-127, 1995.

[17] Jones, Jr, J.B. \& Case, V.W., Sampling, handling and analyzing plant tissue samples. Soil Testing and Plant Analysis, ed. W.L. Westermaan, Soil Science Society of America: Madison, WI, pp. 389-427, 1990.

[18] HACH, HACH (DR/2000) Spectrophotometer Handbook, HACH Company: Loveland, CO, pp. 295-298, 2000.

[19] Patton, J.J., Burras, L., Konen, M.E. \& Molstad, N.E., An accurate and inexpensive apparatus and method for teaching and measuring stable aggregate content of soils. Journal of Natural Resource and Life Science Education, 30, pp. 84-88, 2001. 
[20] Baker, G.R. \& Hartge, K.H., Bulk density, Methods of Soil Analysis. Part 1. Physical and Mineralogical Methods, ed. K. Arnold, American Society of Agronomy Inc: Madison, WI, pp. 363-375, 1986.

[21] Havlin, J.L., Beaton, J.D., Tisdale, S.L. \& Nelson, W.L., Soil Fertility and Fertilizers: An Introduction to Nutrient Management, 6th edn, Prentice Hall: New Jersey, 1999.

[22] Kathju, S., Burman, U. \& Garg, B.K., Influence of nitrogen fertilization on water relations, photosynthesis, carbohydrate and nitrogen metabolism of diverse pearl millet genotypes under arid conditions. Journal of Agricultural Science, Cambridge, 137, pp. 307-318, 2001.

[23] Salisbury, F.B. \& Ross, C.W., Assimilation of nitrogen and sulfur. Plant Physiology, Wadsworth Publ. Co. Inc: Belmont, CA, pp. 192-204, 1982.

[24] Corine, C. de Groot, Riki van den Boogaard, Leo, F.M.M., Jeremy, H. \& Hans, L., Contrasting effects of $\mathrm{N}$ and $\mathrm{P}$ deprivation on the regulation of photosynthesis in tomato plants in relation to feedback limitation. Journal of Experimental Botany, 54(389), pp. 1957-1967, 2003.

[25] Teng, Y. \& Timmer, V.R., Nitrogen and phosphorus interactions in an intensively managed nursery soil-plant system. Soil Science Society of America Journal, 58, pp. 232-238, 1994.

[26] Roostalu, H., Poldma, P. \& Joudu, J., Application of fertilizer and nitrogen balance in Estonian Soils. ISHS Workshop on Environmental Problems Associated with Nitrogen Fertilization of Field Grown Vegetable Crops, Potsdam, August 30-September 1, 1999.

[27] Prasad, R. \& Power, J.F., Soil Fertility Management for Sustainable Agriculture, CRC, Lewis Publishers: Boca Raton, FL, 1997.

[28] Lopez Cruz, I.L., van Willigenburg, L.G. \& van Straten, G., Optimal control of nitrate in lettuce by a hybrid approach: differential evolution and adjustable control weight gradient algorithms. Computer and Electronics in Agriculture, 40, pp. 179-197, 2003.

[29] MAFF UK, Nitrate in lettuce and spinach, Food surveillance information sheet number 177, Joint Food Safety and Standards Group, http://www.maff.gov.uk/food/infsheet/1999/no177/ 177nitra.htm, 1999.

[30] Landon, J.R., Booker Tropical Soil Manual: A Handbook for Soil Survey and Agricultural Land Evaluation in the Tropics and Subtropics, Longman Scientific \& Technical: Essex, UK, 1991.

[31] Belanger, G., Bregard, A. \& Michaud, R., Phosphorus uptake and concentrations of timothy genotypes under varying N applications. Crop Science, 42, pp. 2044-2048, 2002.

[32] Sims, J.T. \& Wolf, D.C., Poultry waste management: agricultural and environmental issues. Advances in Agronomy, 50, pp. 1-83, 1994.

[33] Tisdale, S.L., Nelson, W.L. \& Beaton, J.D., Soil Fertility and Fertilizers, 4th edn, Macmillan Publishing Company: New York, 1985.

[34] Caravaca, F., Lax, A. \& Albaladejo, J., Soil aggregate stability and organic matter in clay and fine silt fractions in urban refuse-amended semiarid soils. Soil Science Society of America Journal, 65, pp. 1235-1238, 2001.

[35] Wang, X., Yost, R.S. \& Linquist, B.A., Soil aggregate size affects phosphorus desorption from highly weathered soils and plant growth. Soil Science Society of America Journal, 65, pp. 139-146, 2001.

[36] Le Bissonnais, Y., Aggregate stability and assessment of soil crustability and erodibility: I. Theory and methodology. European Journal of Soil Science, 47, pp. 425-437, 1996.

[37] Cruse, R.M., Cassel, D.K. \& Averette, F.G., Effect of particle surface roughness on densification of coarse-textured soil. Soil Science Society of America Journal, 44, pp. 692-697, 1980.

[38] De Smet, J., Wontroba, J., De Bood, M. \& Hartmann, R., Effects of application of pig slurry on soil penetration resistance and sugar beet emergence. Soil and Tillage Research, 19, p. 297, 1991. 
[39] Tam, N.F.Y. \& Wong, Y.S., Spatial variation of heavy metal in surface sediments of Hong Kong mangrove swamps. Environmental Pollution, 110, pp. 195-205, 2000.

[40] Ross, S.M. \& Kaye, K.J., The meaning of metal toxicity in soil-plant systems. Toxic Metals in Soil-Plant Systems, ed. S.M. Ross, Wiley and Sons: Ontario, Canada, pp. 27-61, 1994.

[41] Wright, P. \& Mason, C.F., Spatial and seasonal variation in heavy metals in the sediments and biota of two adjacent estuaries, the Orwell and the Stour, in eastern England. Science of Total Environment, 226, pp. 139-156, 1999.

[42] Horticulture Australia, Managing cadmium in vegetables, www.cadmium-management.org.au, 2003.

[43] Rahman, M.M. \& Preeda, P., Distribution of arsenic in kangkong (Ipomoea reptans). Science Asia, 30, pp. 255-259, 2004. 